\title{
HUBUNGAN PRESTASI AKADEMIK DENGAN RIWAYAT PEMBERIAN ASI PADA ANAK
}

\author{
Tity Wulandari \\ Universitas Islam Sumatera Utara, JI. STM No. 77 Medan
}

Email : titywulandari@yahoo.com

\begin{abstract}
Breast milk is milk which produced by mother's breast glands for infants consumption and is the main source of nutrition for infants who have not been able to digest solid foods. This research is motivated by the problems of many mothers who switched to using formula milk instead of breastfeeding their children. The purpose of this study to find the relationship of academic achievement with history of breast milk in children in Elementary School 060818 Medan City District. This research use analytical method with cross sectional design approach. The measuring tool used is questionnaire. The population of this study are the students of Elementary School 060818 Medan City District. The sampling was taken on the 5th and 6th graders, there were 82 students who meet the inclusion criteria. Data to be analyzed using independent $t$-test. The results showed that students who consumed exclusive breastfeeding were 26 student (31.7\%) and who did not consume exclusive breastfeeding were 56 student (68.3\%).Average academic achievement of children who consumed exclusive breastfeeding 73.6 and the average achievement of children who did not consume exclusive breastfeeding 74.9. Based on the results of statistical tests using independent $t$-test, $p=0.35$, it is concluded that there is no significant difference at academic achievement between the exclusive breastfeeding and the formula milk students.
\end{abstract}

Keyswords: Academic Achievements, Breast Milk, Elementary School

\section{PENDAhUlUAN}

Air Susu Ibu (ASI) merupakan makanan terbaik bagi bayi yang baru dilahirkannya. Komposisi ASI berubah setiap saat sesuai dengan apa yang dikonsumsi Ibu. Komposisi ASI dapat memenuhi kebutuhan bayi dan merupakan makanan tunggal untuk memenuhi kebutuhan bayi agar dapat tumbuh secara optimal sampai usia 6 bulan. Selain itu ASI mengandung antibodi seperti makrofag, limfosit dan antibodi yang dapat mencegah bayi terinfeksi penyakit tertentu. Pemberian
ASI juga berpengaruh terhadap biologis dan emosional yang luar biasa terhadap kesehatan ibu dan anak serta terdapat hubungan yang erat antara pemberian ASI eksklusif dan penjarangan kelahiran. serta keuntungan ekonomi (Oktavia \& Yulius, 2014)

Pemberian ASI eksklusif adalah pemberian ASI saja tanpa makanan pendamping lainnya, seperti susu formula, jeruk, madu, air teh, air putih maupun tambahan makanan padat 
seperti pisang, pepaya, bubur susu, biskuit, bubur nasi dan tim, sejak bayi lahir sampai usia sekitar 4-6 bulan (Setyowati \& Rahayu, 2008).

Pada awal hidupnya, bayi membutuhkan nutrisi yang adekuat untuk pertumbuhannya, sehingga dapat mengoptimalkan seluruh proses tumbuh kembangnya. ASI merupakan cairan nutrisi komplek yang mengandung semua nutrient yang diperlukan tubuh anak. Sifat ASI sangat mudah diserap tubuh bayi, menjadikannya nutrisi utama yang paling memenuhi persyaratan untuk tumbuh kembang bayi.

Pemberian ASI juga dapat memenuhi kebutuhan emosi seperti kasih saying yang akan mampu meningkatkan ikatan batin antara ibu dan bayi. Pemberian ASI menjadi penting karena turut berperan dalam menentukan perilaku/kepribadian anak dikemudian hari, merangsang perhatian anak terhadap lingkungan sekitar, menstimulasi perkembangan otak anak dan meningkatkan rasa kepercayaan diri anak yang terbentuk dari rasa aman dan nyaman pada saat disusui (Murdiningsih \& Ayu, 2013).

Menyusui sejak dini memberikan dampak yang positif tidak saja bagi bayi tetapi juga bagi ibu. Mengkonsumsi susu bagi bayi berperan penting untuk menunjang pertumbuhan, kesehatan, dan kelangsungan hidup bayi karena ASI kaya dengan zat gizi dan antibodi. Sedangkan menyusui dapat mengurangi morbiditas dan mortalitas ibu karena proses menyusui mampu merangsang kontraksi uterus yang akan mengurangi perdarahan pasca melahirkan (postpartum) (Fikawati \& Syafiq, 2003).

ASI mengandung nutrisi penting yang dibutuhkan bayi diantaranya adalah protein, karbohidrat, dan lemak yang terkumpul pada kelenjar alveolar payudara. Protein dalam ASI merupakan nutrisi yang mudah dicerna disbanding protein yang tersedia dalam susu formula. Protein dalam ASI mengandung sekitar $6 \%$ kalori.

Laktosa merupakan nutrisi lain dalam ASI yang menjadi karbohidrat utama bagi bayi. Karbohidrat dalam ASI mengandung sekitar $42 \%$ kalori. Kandungan lainnya dalam ASI adalah kolesterol yang merupakan zat yang berperan dalam perkembangan otak paling tinggi. Lemak juga terkandung dalam ASI yaitu sekitar $52 \%$ kalori. ASI juga mengandung vitamin dan mineral yang ditransfer dari plasma maternal dan antibody yang dapat mengurangi bahaya infeksi pada bayi baru lahir. Inilah alasan penting bagi Ibu dalam memberikan ASI secara eksklusif. Pmberian ASI dapat meningkatkan perkembangan pada bayi karena semua unsur nutrisi yang dibutuhkan bayi untuk mencapai tahap perkembangan tersebut, dapat dipenuhi oleh ASI (Pratama \& Budiati, 2013).

Keuntungan pemberian ASI menurut Soetjiningsih (2012) antara lain: steril, aman dari pencemaran kuman; selalu tersedia dengan suhu yang optimal; produksinya menyesuaikan dengan kebutuhan bayi; mengandung antibodi yang dapat menghambat pertumbuhan kuman atau bahkan mampu membunuh kuman atau virus; tidak ada bahaya alergi; menjalin hubungan yang lebih erat antara bayi dan ibunya; menyebabkan uterus berkontraksi sehingga pengembalian uterus ke keadaan fisiologis (sebelum kehamilan) lebih cepat; mengurangi resiko perdarahan setelah melahirkan tipe lambat; mengurangi kemungkinan resiko menderita kanker payudara pada masa mendatang; kesuburan ibu akan 
Jurnal Kesehatan Masyarakat \& Gizi, e-ISSN: 2655-0849

Vol. 1 No.2 Edisi November 2018-April 2019

https://ejournal.medistra.ac.id/index.php/JKG

Received: 12 Februari 2019 :: Accepted: 25 April 2019 :: Published: 29 April 2019

berkurang untuk beberapa bulan sehingga membantu keluarga berencana.

Kenyataan di lapangan menunjukkan adanya berbagai hambatan atau permasalahan terhadap rendahnya pemberian ASI eksklusif seperti faktor ibu yang kurangnnya pengetahuan tentang manfaat menyusui secara eksklusif, kurangnya atau tidak adanya dukungan suami kepedulian keluarga dan masyarakat dalam menyukseskan pemberian ASI eksklusif, lemahnya informasi/ promosi tentang pemberian ASI eksklusif oleh tenaga kesehatan. Penyebab lain yang sangat berpengaruh pada penurunan pemakaian ASI eksklusif adalah gencarnya promosi susu formula pengganti ASI yang menawarkan keunggulan semu (Murdiningsih \& Ayu, 2013).

Salah satu faktor yang mempengaruhi kecerdasan adalah pemenuhan nutrisi saat bayi terutama ASI. Pemberian ASI juga berperan penting dalam mempengaruhi kemampuan pemahaman dan analisis anak sehingga dapat meningkatkan nilai akademik (Ambelina, dkk, 2014).

Prestasi belajar merupakan hasil dari kemampuan siswa dalam menerima, menolak dan menilai informasiinformasi yang diperoleh dalam proses belajar mengajar. Prestasi belajar seseorang menyesuaikan tingkat keberhasilan dalam mempelajari materi pelajaran yang dinyatakan dalam bentuk nilai atau raport setiap bidang studi setelah mengalami proses belajar mengajar. Prestasi belajar siswa dapat diketahui setelah diadakan evaluasi. Hasil dari evaluasi dapat memperlihatkan tentang tinggi atau rendahnya prestasi belajar siswa (Hamdu \& Agustina, 2011).
Adapun hasil dalam kegiatan belajar diartikan sebagai kinerja akademik atau prestasi belajar. Hasil belajar berfungsi untuk mengetahui tingkat kemajuan atau penguasaan yang telah dicapai siswa dalam segala aspek meliputi ranah cipta (prestasi kognitif), ranah rasa (prestasi afektif) dan ranah karsa (prestasi psikomotorik). Guna mengungkapkan hasil belajar diperlukan beragam norma pengukuran untuk menetapkan tingkat keberhasilan siswa dalam mengikuti proses pembelajaran (Prastiti \& Pujingsih, 2009).

Faktor yang mempengaruhi nilai prestasi belajar selain faktor pemberian ASI ekslusif diantaranya yang berasal dari dalam tubuh meliputi: gizi yang terpenuhi, kesehatan, kebiasaan sarapan pagi, intelegensi dan konsentrasi siswa, sikap, bakat, minat, motivasi. Faktor yang berasal dari luar tubuh meliputi: sekolah, masyarakat, waktu belajar, faktor lingkungan yang dapat mengganggu proses belajar (Ratnasari dkk, 2015).

Sedangkan faktor genetik (IQ orang tua), pengetahuan orang tua, pola asuh, lingkungan rumah dan sekolah, fasilitas belajar, dan sosio-ekonomi keluarga dan pola pemberian ASI tidak mempengaruhi tingkat kecerdasan anak secara bermakna (Ambelina dkk, 2014).

Status gizi yang baik merupakan salah satu factor penentu keberhasilan pembangunan nasional. Gizi yang baik akan menghasilkan Sumber Daya Manusia (SDM) yang berkualitas yaitu sehat, cerdas, dan memiliki fisik yang tangguh dan produktif (Fikawati \& Syafiq, 2003). Prestasi belajar yang baik dapat menjadi indicator kualitas seorang siswa, dimana hal ini akan memberikan kontribusi terhadap keberhasilan pembangunan. 


\section{METODE PENELITIAN}

Penelitian ini dilakukaan di SD Negeri 060818 Kecamatan Medan Kota pada bulan April 2017 sampai dengan selesai. Teknik pengambilan sampel dalam penelitian ini menggunakan total sampling yaitu seluruh siswa/siswi kelas 5 dan 6 SD Negeri 060818 kecamatan Medan Kota dijadikan sampel.

Instrumen penelitian adalah alat-alat yang digunakan pada waktu penelitian untuk mengumpulkan data (Arikunto, 2006). Dalam penelitian ini instrumen yang digunakan adalah kuesioner yang di bagikan kepada orang tua siswa dan hasil rekapitulasi nilai siswa yang diminta kepada pihak sekolah.

Data-data yang telah dikumpulkan, diolah dan dianalisis untuk mendapatkan gambaran hubungan antara variabel independen (ASI Eksklusif dan ASI tidak Eksklusif) dan variabel dependen (Prestasi Akademik). Data dianalisis menggunakan uji independent $t$-test untuk melihat hubungan antara beberapa variabel tersebut dengan nilai $p$ value $<0,05$.

\section{HASIL PENELITIAN}

\section{Karakteristik Responden}

Dari 82 siswa yang ada di kelas 5 dan 6 SD Negeri 060818 Kecamatan medan Kota didapatkan 26 orang yang mengonsumsi ASI Eksklusif dan 56 orang yang tidak mengonsumsi ASI Eksklusif. Karakteristik responden yang ada dapat dibedakan berdasarkan usia, kelas, jenis kelamin, pendidikan ibu, pekerjaan ibu, konsumsi ASI, dan prestasi akademik. Untuk lebih jelas dapat dilihat pada tabel dibawah ini.

Tabel 1 Distribusi Frekuensi dan

Persentase berdasarkan Usia

\begin{tabular}{ccc}
\hline Usia & Frekuensi & Persentase \\
\hline 10 & 21 & 25.6 \\
11 & 37 & 45.1 \\
12 & 24 & 29.3 \\
\hline
\end{tabular}

Total

82

100

Berdasarkan Tabel 1, diketahui bahwa dari 82 siswa, terdapat 21 (25,6\%) siswa dengan usia 10 tahun, 37 $(45,1 \%)$ siswa berusia 11 tahun dan 24 $(29,3 \%)$ siswa berusia 12 tahun. Tabel 4.2 disajikan distribusi frekuensi dan persentase berdasarkan kelas.

Tabel 2 Distribusi Frekuensi dan Persentase berdasarkan Kelas

\begin{tabular}{ccc}
\hline Kelas & Frekuensi & Persentase \\
\hline 5 & 42 & 51.2 \\
6 & 40 & 48.8 \\
\hline Total & 82 & 100 \\
\hline
\end{tabular}

Berdasarkan Tabel 2, diketahui bahwa dari 82 siswa, terdapat 42 (51,2\%) siswa kelas 5 SD, sementara terdapat $40(48,8 \%)$ siswa kelas 6 SD. Tabel 4.3 disajikan distribusi frekuensi dan persentase berdasarkan jenis kelamin.

Tabel 3 Distribusi Frekuensi dan Persentase berdasarkan Jenis Kelamin

\begin{tabular}{ccc}
\hline $\begin{array}{c}\text { Jenis } \\
\text { Kelamin }\end{array}$ & $\begin{array}{c}\text { Frekuens } \\
\text { i }\end{array}$ & $\begin{array}{c}\text { Persentas } \\
\text { e }\end{array}$ \\
\hline Laki-Laki & 34 & 41.5 \\
Perempuan & 48 & 58.5 \\
\hline Total & 82 & 100 \\
\hline
\end{tabular}

Berdasarkan Tabel 3, diketahui bahwa dari 82 siswa, terdapat $34(41,5 \%)$ siswa dengan jenis kelamin laki-laki, sementara terdapat $48(58,5 \%)$ siswa dengan jenis kelamin perempuan. Tabel 4.4 disajikan distribusi frekuensi dan persentase berdasarkan pendidikan ibu.

Tabel 4 Distribusi Frekuensi dan Persentase berdasarkan Pendidikan Ibu Pendidika Frekuens Persentase 


\begin{tabular}{ccc}
\hline n Ibu & i & \\
\hline SD & 4 & 4.9 \\
SLTP & 19 & 23.2 \\
SLTA & 40 & 48.8 \\
S1 & 19 & 23.2 \\
\hline Total & 82 & 100 \\
\hline
\end{tabular}

yang mengonsumsi ASI eksklusif dinyatakan pada tabel berikut.

Tabel 6 Distribusi Frekuensi dan Persentase berdasarkan Konsumsi ASI Eksklusif

\begin{tabular}{ccc}
\hline $\begin{array}{c}\text { Konsumsi } \\
\text { ASI } \\
\text { Eksklusif }\end{array}$ & $\begin{array}{c}\text { Frekuens } \\
\mathbf{i}\end{array}$ & $\begin{array}{c}\text { Persentas } \\
\mathbf{e}\end{array}$ \\
\hline Ya & 26 & 31.7 \\
Tidak & 56 & 68.3 \\
\hline Total & 82 & 100 \\
\hline
\end{tabular}

Berdasarkan Tabel 4, diketahui terdapat $4 \quad(4,9 \%)$ ibu dengan pendidikan SD, $19(23,2 \%)$ ibu dengan pendidikan SLTP, $40 \quad(48,8 \%)$ ibu dengan pendidikan SLTA dan 19 $(23,2 \%)$ ibu dengan pendidikan $\mathrm{S} 1$. Adapun karaktersitik pekerjaan ibu dari sampel penelitian ini ditayangkan dalam tabel 5 berikut.

Tabel 5 Distribusi Frekuensi dan Persentase berdasarkan Pekerjaan Ibu

\begin{tabular}{|c|c|c|}
\hline $\begin{array}{c}\text { Pekerjaan } \\
\text { Ibu }\end{array}$ & Frekuensi & Persentase \\
\hline Bekerja & 22 & 26.8 \\
\hline Tidak Bekerja & 60 & 73.2 \\
\hline Total & 82 & 100 \\
\hline
\end{tabular}

Berdasarkan Tabel 5, diketahui terdapat $22(26,8 \%)$ ibu yang memiliki pekerjaan, sementara $60(73,2 \%)$ ibu tidak bekerja atau ibu rumah tangga. Adapun untuk karakteristik sampel

Berdasarkan Tabel 6, diketahui terdapat $26 \quad(31,7 \%)$ ibu yang memberikan ASI eksklusif, sementara $56(68,3 \%)$ ibu tidak memberikan ASI eksklusif.

Selanjutnya, berdasarkan tabel 7, diketahui bahwa rata-rata prestasi akademik dari anak yang diberi ASI eksklusif adalah 73,6. Rata-rata prestasi akademik dari anak yang tidak diberi ASI eksklusif adalah 74,9. Secara rata-rata, nilai prestasi akademik dari anak yang tidak diberi ASI eksklusif lebih tinggi dibandingkan anak yang diberi ASI eksklusif.

Tabel 7 Rata-Rata Prestasi Akademik antara Anak yang Diberi ASI Eksklusif dan Tidak

\begin{tabular}{ccccc}
\hline & $\begin{array}{c}\text { Konsumsi ASI } \\
\text { Eksklusif }\end{array}$ & $\mathrm{N}$ & Mean & P-Value \\
\hline Nilai Rata-Rata & Ya & 26 & 73.6 & 0.351 \\
Akademik & Tidak & 56 & 74.9 & \\
\hline
\end{tabular}

Berdasarkan hasil pengujian statistik dengan menggunakan uji independent t-test, diperoleh nilai $p=0,351>0,05$, maka disimpulkan bahwa secara ratarata tidak terdapat perbedaan yang terlalu signifikan, antara prestasi akademik anak yang diberi ASI eksklusif dan prestasi akademik anak yang tidak diberi ASI eksklusif.

Tabel 8 Perbandingan Rata-Rata Prestasi Akademik antara Anak yang Diberi ASI Eksklusif dan Tidak

\begin{tabular}{cccccc}
\hline $\begin{array}{c}\text { Konsumsi ASI } \\
\text { Eksklusif }\end{array}$ & $\begin{array}{c}\text { Kelom } \\
\text { pok }\end{array}$ & Mean & $\begin{array}{c}\text { Std. } \\
\text { Devias }\end{array}$ & $\mathrm{n}$ & $\begin{array}{c}\text { Persenta } \\
\text { se }\end{array}$ \\
\hline
\end{tabular}




\begin{tabular}{cccccc}
\hline & Nilai & \multicolumn{5}{c}{ i } \\
\hline Ya & $<70$ & 66.5 & 3.2 & 8 & $30.8 \%$ \\
& $>70$ & 76.7 & 4.0 & 18 & $69.2 \%$ \\
& Total & 73.6 & 6.1 & 26 & $100 \%$ \\
\hline Tidak & $<70$ & 66.5 & 2.9 & 13 & $23.2 \%$ \\
& $>70$ & 77.4 & 3.8 & 43 & $76.8 \%$ \\
& Total & 74.9 & 5.9 & 56 & $100 \%$ \\
\hline Sampel & $<70$ & 66.5 & 2.9 & 21 & $25.6 \%$ \\
& $>70$ & 77.2 & 3.8 & 61 & $74.4 \%$ \\
& Total & 74.5 & 5.9 & 82 & $100 \%$ \\
\hline
\end{tabular}

Tabel 8 Menunjukkan bahwa rata-tata akademik pada kelompok ASI eksklusif dengan kelompok nilai $<70$ adalah 66,5 , dengan jumlah anak sebanyak 8 orang, rata-tata akademik pada kelompok ASI eksklusif dengan kelompok nilai > 70 adalah 76.7, dengan jumlah anak sebanyak 18 orang, rata-tata akademik pada kelompok ASI tidak eksklusif dengan kelompok nilai < 70 adalah 66.5, dengan jumlah anak sebanyak 13 orang dan rata-tata akademik pada kelompok ASI tidak eksklusif dengan kelompok nilai > 70 adalah 77.4, dengan jumlah anak sebanyak 43 orang.

Tabel 9 Persentase berdasarkan kelompok nilai

\begin{tabular}{|c|c|c|c|c|c|}
\hline \multicolumn{2}{|c|}{$\begin{array}{l}\text { Konsumsi } \\
\text { ASI }\end{array}$} & \multicolumn{2}{|c|}{$\begin{array}{c}\text { Kelompok } \\
\text { Nilai }\end{array}$} & \multirow{3}{*}{$\begin{array}{c}\text { Tota } \\
\text { I }\end{array}$} & \multirow{3}{*}{$\begin{array}{c}\text { P- } \\
\text { Valu } \\
\text { e }\end{array}$} \\
\hline & & $<$ & $>70$ & & \\
\hline & & 70 & & & \\
\hline \multirow[t]{2}{*}{ Ya } & $f$ & 8 & 18 & 26 & \\
\hline & $\%$ & $\begin{array}{c}30 . \\
8\end{array}$ & 69.2 & 100 & 0,46 \\
\hline \multirow{2}{*}{$\begin{array}{c}\text { Tida } \\
\text { k }\end{array}$} & $f$ & 13 & 43 & 56 & 6 \\
\hline & $\%$ & $\begin{array}{c}23 . \\
2\end{array}$ & 76.8 & 100 & \\
\hline \multirow[t]{2}{*}{ Total } & $f$ & 21 & 61 & 82 & \\
\hline & $\%$ & $\begin{array}{c}25 . \\
6\end{array}$ & 74.4 & 100 & \\
\hline
\end{tabular}

Tabel 9 Menyatakan bahwa terdapat 26 yang mengkonsumsi ASI eksklusif, $8(30,8 \%)$ di antaranya masuk ke dalam kelompok nilai kurang dari 70 dan 18 (69,2\%) masuk ke dalam kelompok nilai lebih dari 70 , terdapat 56 yang tidak mengkonsumsi asi eksklusif, $13(23,2 \%)$ di antaranya masuk ke dalam kelompok nilai kurang dari 70 dan $43(76,8 \%)$ masuk ke dalam kelompok nilai lebih dari 70 dan dengan nilai $p$-value 0,466 yang lebih besar dari 0,05, maka dapat diartikan bahwa tidak terdapat hubungan yang signifikan antara konsumsi ASI eksklusif dengan nilai siswa.

\section{PEMBAHASAN}

Penelitian yang dilakukan terhadap 82 responden siswa/i kelas 5 dan 6 SDN 060818 kecamatan medan kota menunjukkan bahwa terdapat 26 orang yang mengonsumsi ASI eksklusif dan 56 orang yang tidak mengonsumsi ASI eksklusif. Kegagalan pemberian ASI Eksklusif kepada anak disebabkan oleh air susu ibu yang tidak lancar, maka dari itu orang tua lebih memilih memberikan susu formula kepada anaknya, sebagian besar alasan memberikan susu formula karna tidak mau repot kalau anaknya rewel dan sebagai penambah berat badan anaknya.

Hasil serupa juga ditemukan dalam penelitian di Bandung yang mengindikasikan bahwa persentase pemberian ASI eksklusif masih rendah, yaitu hanya sebesar $20,4 \%$ ibu yang berdomisili di wilayah tersebut yang memberi bayinya ASI eksklusif (Widiyanto dkk, 2012) 
Sama halnya dengan penelitian di Jogyakarta yang mengatakan ada beberapa faktor yang membuat sebagian ibu muda tidak menyusui anaknya (Prasetyono, 2009). Ada empat alasan yang menjadi penyebabnya. Pertama, gencarnya kampanye produk susu dan makanan pengganti ASI, serta keberhasilan para distributor dalam mendistribusikannya kepada masyarakat, sehingga para ibu tergerak untuk mempercayainya. Kedua, rendahnya kesadaran ataupun pengetahuan para ibu akan manfaat ASI Eksklusif sebagai makanan utama bayi. Ketiga, kurangnya perhatian para ahli kesehatan/penyuluh kesehatan untuk menggalakkan kebiasaan menyusui anak. Keempat, kurang lancarnya program kesejahteraan sosial yang terarah yang dijalankan oleh beberapa instansi pemerintahan di negara-negara berkembang (Prasetyono, 2009)

Tidak saja di kota Medan ini, Hasil serupa juga ditemukan dalam penelitian yang dilakukan di kota Palembang, tidak terdapat hubungan antara pemberian ASI eksklusif terhadap tingkat kecerdasan anak (Murdiningsih \& Ayu, 2013)

Berbeda dengan hasil penelitian yang dilakukan di Semarang, Ratnasari (2015) memperoleh kesimpulan yang berbalik dengan penelitian ini, yaitu terdapat hubungan antara riwayat pemberian ASI eksklusif dengan nilai prestasi belajar, anak yang diberikan ASI Eksklusif memiliki kemungkinan 3 kali lebih besar untuk memiliki tingkat kecerdasan rata-rata.

Kurang gizi pada anak berhubungan erat dengan pencapaian akademik anak di sekolah menyebabkan kurang konsentrasi saat belajar. Dari hasil penelitian di padang yang mengatakan diantara 77 responden hanya sebanyak
50 responden yang memiliki status gizi normal. Didapatkan sebanyak 48 dari 50 responden (96\%) yang memiliki prestasi belajar baik dan hanya 2 orang (4\%) responden yang memiliki prestasi belajar kurang (Fikawati, 2003).

Anemia dapat menimbulkan dampak negatif yang berpengaruh pada aktivitas sehari-hari seperti: berkurangnya daya pikir dan konsentrasi, berkurangnya prestasi, berkurangnya semangat belajar dan bekerja, menurunnya produktivitas kerja, menurunnya kebugaran tubuh, mudah terserang penyakit sehingga dapat menurunkan prestasi belajar pada siswi. Dari hasil penelitian Prastiti \& Pujingsih (2009) di Yogyakarta yang mengatakan dari 18 responden yang mengalami anemia ringan sebanyak 8 orang $(44 \%)$ berprestasi baik, yang mengalami anemia ringan 4 orang (22\%) berprestasi cukup, dan anemia berat 1 orang $(5,6 \%)$ berprestasi kurang. Berdasarkan data tersebut dapat diketahui bahwa ada hubungan antara anemia dengan prestasi belajar.

\section{KESIMPULAN}

Berdasarkan hasil penelitian yang dilanjutkan dengan pembahasan hasil penelitian ini maka hanyadapat disimpulkan sebagaiberikut:

1. Hasil rekapitulasi kuesioner, dapat diketahui bahwa siswa/siswi SD Negeri 060818 Kecamatan Medan Kota yang minum ASI selama 6 bulan penuh sebanyak 26 orang $(31,7 \%)$ sedangkan yang tidak minum ASI sebanyak 56 orang $(68,3 \%)$.

2. Berdasarkan hasil penelitian diketahui bahwa rata-rata prestasi akademik dari anak yang diberi ASI eksklusif adalah 73,6. Rata-rata prestasi akademik dari anak yang tidak diberi ASI eksklusif adalah 74,9 . Secara rata-rata, nilai prestasi 
Jurnal Kesehatan Masyarakat \& Gizi, e-ISSN: 2655-0849

Vol. 1 No.2 Edisi November 2018-April 2019

https://ejournal.medistra.ac.id/index.php/JKG

Received: 12 Februari 2019 :: Accepted: 25 April 2019 :: Published: 29 April 2019

akademik dari anak yang tidak diberi ASI eksklusif lebih tinggi dibandingkan anak yang diberi ASI eksklusif.

3. Berdasarkan hasil pengujian statistic dengan menggunakan $u \mathrm{ji}$ independent $t$-test, diperoleh nilai $\mathrm{p}$ $=0,351(>0,05)$, maka disimpulkan bahwa secara rata-rata tidak terdapat perbedaan yang terlalu signifikan, antara prestasi akademik anak yang diberi ASI eksklusif dan prestasi akademik anak yang tidak diberi ASI eksklusif.

4. Berdasarkan hasil penelitian diketahui bahwa rata-rata akademik pada kelompok ASI eksklusif dengan kelompok nilai kurang dari 70 adalah 66,5 (30.8\%), dengan jumlah anak sebanyak 8 orang. Rata-rata akademik pada kelompok ASI eksklusif dengan kelompok nilai lebih dari 70 adalah 76.7 (69.2\%), dengan jumlah anak sebanyak 18 orang. Rata-rata akademik pada kelompok ASI tidak eksklusif dengan kelompok nilai kurang dari 70 adalah 66.5 (23.2\%), dengan jumlah anak sebanyak 13 orang. Rata-rata akademik pada kelompok ASI tidak eksklusif dengan kelompok nilai lebih dari 70 adalah $77.4(76.8 \%)$, dengan jumlah anak sebanyak 43 orang. Maka nilai $p-$ value 0,466 , disimpulkan bahwa tidak terdapat hubungan yang signifikan antara konsumsi ASI eksklusif dengan nilai siswa.

\section{DAFTAR PUSTAKA}

Oktavia, N. S., Yulius, O. Y., 2014. Faktor Faktor yang Berhubungan dengan Prestasi Belajar pada Siswa Sekolah Dasar Negeri 47 Korong Gadang Kecamatan Kuranji Kota Padang Tahun 2014. Kebidanan Poltekes Kemenkes Republik Indonesia Padang.
Setyowati, E., Rahayu, F. B., 2008. Hubungan Pengetahuan Tenaga Kesehatan Tentang ASI Eksklusif dengan Kemampuan Memberikan Pendidikan Kesehatan ASI Eksklusif pada Ibu Prenatal di Puskesmas II Kartasura. Berita Ilmu Keperawatan Vol. 1 (2).

Murdiningsih., MB, C., Ayu, A., 2013. ASI Eksklusif dan Tingkat Kecerdasan Anak di Taman Kanak-Kanak. Kebidanan Poltekes Palembang Kementrian Kesehatan Indonesia

Fikawati, S., Syafiq, A., 2003. Hubungan antara Menyusui Segera (immediate breastfeeding) dan Pemberian ASI Eksklusif sampai dengan empat bulan. Fakultas Kesehatan Masyarakat Universitas Indonesia

Pratama, A M., Tri Budiati. 2013. Perkembangan Bayi yang Diberikan ASI Eksklusif dan Tidak Eksklusif. Fakultas Ilmu Kedokteran, Universitas Indonesia.

Soetjiningsih. 2012. ASI petunjuk Untuk Tenaga Kesehatan.Jakarta: EGC

Ambelina, S., Chundrayatti., Lipoeto, N. I., 2014. Hubungan Riwayat Pola Pemberian ASI dengan Tingkat Kecerdasan Anak SD di SDN 01 Sawahan Kecamatan Padang Timur Kota Padang. Jurnal Fakultas Kedokteran Universitas Andalas.

Ratnasari, F., Dewiyanti, L., Anggraini, M. T., 2015. Hubungan Pemberian ASI Eksklusif dengan Prestasi Belajar Siswa Sekolah Dasar. Jurnal Kedokteran Muhammadiyah Vol. 2 (1).

Widiyanto, S., Aviyanti, D., Tyas, M., 2012. Hubungan Pendidikan dan Pengetahuan Ibu tentang ASI Eksklusif dengan Sikap terhadap Pemberian ASI Eksklusif. Fakultas Kedokteran Universitas Muhammadiyah Semarang 
Jurnal Kesehatan Masyarakat \& Gizi, e-ISSN: 2655-0849

Vol. 1 No.2 Edisi November 2018-April 2019

https://ejournal.medistra.ac.id/index.php/JKG

Received: 12 Februari 2019 :: Accepted: 25 April 2019 :: Published: 29 April 2019

Prasetyono, D.S. 2009. Buku Pintar ASI Eksklusif .Jogjakarta: DIVA Press

Hamdu, G., Agustina, L., 2011. Pengaruh Motivasi Belajar Siswa Terhadap Prestasi Belajar IPA di Sekolah Dasar. Jurnal Penelitian Pendidikan Vol. 12 (1).
Prastiti, S. D., Pujingsih, S., 2009. Pengaruh Faktor Preverensi Gaya belajar terhadap Prestasi Belajar Mahasiswa Akuntansi. Jurnal Ekonomi Bisnis No 3. 